\title{
KETIKA PEREMPUAN TIDAK CANTIK: ANALISIS ATAS REPRESENTASI PEREMPUAN DALAM WEBTOON THE SECRET OF ANGEL
}

\author{
Vini Fahira Amru \\ Program Studi Ilmu Komunikasi FISIP \\ Universitas Jenderal Soedirman \\ Purwokerto \\ vini.amru@mhs.unsoed.ac.id \\ Mite Setiansah \\ Program Studi Ilmu Komunikasi FISIP \\ Universitas Jenderal Soedirman \\ Purwokerto \\ mite.setiansah@unsoed.ac.id
}

\begin{abstract}
Beautiful or not is a socio-cultural construction that is very relative and can be different in every place, time and culture. However, there are beauty standards that are often used as ideal indicators for women to be considered beautiful. When women are deemed not meeting these criteria, then they will be vulnerable to various discriminatory treatment from their environment. As a result, women must always strive to meet these beautiful standards in various ways including using make-up. This condition was revealed in the analysis of the digital comic The Secret of Angel. The analysis was carried out using mix methods approach to 89 comic episodes. The results of the analysis show that quantitatively (66\%) of the utterances addressed to women, especially the main character, are positive, but qualitatively when attached to the context, the positive representation does not necessarily have a positive connotation and frees women from discriminatory treatment.
\end{abstract}

Key Words: Woman, beautiful, Webtoon, discrimination

\section{Pendahuluan}

Perempuan dan kecantikan adalah dua hal yang tidak dapat dipisahkan. Dalam kontruksi sosial dominan, perempuan cantik selalu memiliki kesempatan untuk mendapat perlakuan lebih baik dari lingkungannya. Persyaratan dalam lowongan pekerjaan, pergaulan, hingga hubungan personal banyak menempatkan faktor penampilan menarik dari perempuan sebagai kriteria penilaian yang penting. Akibatnya perempuan selalu berusaha keras untuk merombak penampilannya agar sesuai dengan kriteria cantik dalam masyarakat. Perempuan juga selalu berusaha untuk menyesuaikan bentuk tubuh mereka dengan apa kata sosial budaya masyarakat mengenai konsep kecantikan tersebut (Hidajadi dalam Ponco, 2017: 2).

Cantik memang relatif namun narasi besar tentang cantik seringkali indentik dengan stereotype visualisasi perempuan cantik yang digambaran oleh Kasiyan (2008:281) sebagai tidak hanya mengarah pada kecantikan wajah, melainkan juga 
pada kulit yang putih, mulus dan kencang, serta bentuk tubuh yang menonjolkan lekukan dan kemontokan organ tertentu, seperti dada dan pinggul, bibir yang sensual, serta segala hal yang terkait dengan organ tubuh perempuan. Kriteria cantik yang hampir senada juga diutarakan oleh Ashad Kusuma Djaya (2007) yang menyebut bahwa kecantikan adalah total, mencakup ukuran-ukuran tubuh (fisik), dan mental atau kepribadian (inner beauty) dengan ukuran standar pula, sehingga secara keseluruhan melahirkan kecantikan sejati.

Menjadi cantik dengan demikian seringkali menjadi impian dan bahkan obsesi banyak perempuan. Namun, tidak semua perempuan mampu memenuhi standar cantik yang diterapkan dalam masyarakat. Ketika seorang perempuan tidak mampu memenuhi standar itu maka melekatlah sejumlah atribut yang berkonotasi negatif pada dia. Perempuan yang dilekati dengan atribut tidak cantik kerapkali mengalami rasa tidak percaya diri, bahkan bisa menyebabkan depresi.

Kontruksi tentang perempuan tidak cantik juga kerap mengalami penguatan melalui berbagai konten media. Perempuan yang direpresentasikan tidak cantik seringkali dihadapkan pada beragam masalah yang tidak menyenangkan. Peran yang diberikan kepada perempuan tidak cantik juga sangat jauh dari karakter yang diperankan oleh para perempuan cantik. Kontruksi media yang demikian secara lama kelamaan turut membentuk makna dan tindakan yang mengarah pada diskriminasi terhadap perempuan akibat penerapan standar kecantikan tersebut. Menurut Theodorson dan Theodorson, (dalam Setyadharma 1979: 115-116) diskriminasi merupakan perlakuan yang tidak seimbang terhadap perorangan, atau kelompok, berdasarkan sesuatu, biasanya bersifat kategorikal atau atribut-atribut khas seperti berdasarkan ras, kesukubangsaan, agama, atau keanggotaan kelas-kelas sosial.

Visualisasi dan diskriminasi perempuan cantik dan tidak cantik tidak hanya terepresentasi dalam konten media-media mainstream, seperti televisi, film, majalah, tabloid, iklan, melainkan juga pada komik baik cetak maupun komik digital atau webtoon. Komik ialah sebuah susunan gambar dan kata yang bertujuan untuk memberikan informasi yang ingin disampaikan kepada pembaca (dalam Soedarso, 2015: 497). Seiring dengan perkembangan zaman komik tidak diterbitkan hanya dalam bentuk strip yang dimuat dalam majalah atau koran maupun buku, tetapi juga diterbitkan secara digital.

Salah satu negara yang mengembangkan komik digital adalah Korea. Para komikus mendapat dukungan secara resmi dari pemerintah Korea sejak 1994 yang melihat komik dan animasi sebagai salah satu dari teknologi bermuatan budaya (culture contents technology). Line Webtoon merupakan salah satu platform penerbitan digital yang dapat diakses baik melalui web maupun telepon seluler secara daring (dalam jaringan). Menariknya, media ini tidak hanya memfokuskan diri pada penerbitan komikus profesional tetapi juga pada mereka yang baru masuk dalam dunia komik (dalam Wawan, 2018: 61).

Salah satu komik yang saat ini memiliki pembaca dalam jumlah yang cukup tinggi adalah komik dengan judul The Secret of Angel. Komik digital The Secret of Angel yang merupakan serial komik Webtoon merupakan komik yang berlatar belakang di Korea Selatan dengan komikus yang berasal dari Korea Selatan juga. Komik ini bercerita tentang betapa kejamnya dunia bagi orang yang tidak cantik. 
Peneliti tertarik untuk meneliti komik digital Webtoon The Secret of Angel dengan tujuan untuk mengungkap dan memperlihatkan kepada pembaca bahwa diskriminasi terhadap perempuan tidak hanya terjadi dalam masyarakat melainkan juga dilanggengkan oleh media termasuk dalam sebuah komik digital. Tujuan penelitian ini adalah memberikan gambaran kepada pembaca bagaimana perempuan menerima perlakuan diskriminatif hanya karena wajahnya tidak cantik.

Sejumlah penelitian tentang diskriminasi terhadap perempuan sudah banyak dilakukan, antara lain penelitian Hossein Khani Arani dan Sajad Davoudi Mobarakeh (2011) dengan judul "Sociolinguistics: Education, Women, Beauty, Discrimination \& Exploitation: Investigating the Ugly Reality". Hasil penelitian menunjukkan bahwa kecantikan memberi pengaruh pada hubungan antara pendidikan dan peluang kerja di sektor swasta. Penelitian lain dilakukan oleh Frank J. Cavico bersama dengan kedua rekannya Stephen C. Muffler dan Bahaudin G. Mujtaba (2012). Mereka melakukan penelitian dengan judul "Appearance Discrimination, "Lookism" And "Lookphobia" In the Workplace" dengan fokus penelitian pada diskriminasi penampilan dan daya tarik tempat kerja di Amerika. Hasil dari penelitian yang dilakukan secara kualitatif ini mengungkap fakta bahwa terdapat perbedaan antara cara manajer dalam menyeleksi karyawan perempuan saat melakukan wawancara. Pelamar kerja yang dianggap kurang menarik memiliki nilai minus dibandingkan dengan perempuan yang dianggap menarik.

Meski penelitian tentang diskriminasi terhadap perempuan telah banyak dilakukan namun penelitian yang berfokus pada representasi dan diskriminasi perempuan dalam komik digital belum banyak dilakukan. Penelitian ini sendiri memiliki hasil yang sangat kontributif terhadap pengembangan wawasan tentang kajian media dan gender khususnya dalam hal pemaknaan cantik dan tidak cantik yang sangat polysemic dan apa implikasi ketika perempuan dipandang tidak cantik.

\section{Metode Penelitian}

Penelitian ini dilakukan dengan menggunakan mix methods. Pengumpulan dan analisis data dilakukan secara dua tahap. Pertama, dengan melakukan analisis isi terhadap komik webtoon The Secret of Angel. Unit analisis yang ditetapkan adalah ujaran atau sebutan positif dan negative yang ditujukan kepada perempuan dan laki-laki yang keluar dalam 89 episode webtoon. Tahap kedua, menggunakan tiga level analisis semiotik dari Roland Barthes, yaitu denotasi, konotasi dan mitos atas representasi perempuan dalam webtoon. Analisis data dilakukan secara deskritif. Menurut Arikunto (1993: 209) analisis data dekriptif bisa dilakukan dengan mengelompokkan data menjadi dua, yaitu data kualitatif berupa kata-kata atau kalimat yang dianalisis dengan membuat kategorisasi dan data kuantitatif yang berupa angka dianalisis dengan teknik statistik deskriptif dan disajikan dalam bentuk table, diagram atau grafik. Upaya untuk meningkatkan tingkat keterpercayaan data dilakukan melalui penerapan teknik triangulasi sumber, metode, dan teori.

\section{Tinjauan Pustaka}

Komik digital adalah media bercerita atau berekspresi dengan bahasa gambar yang tersusun dan diakses menggunakan media digital. Sebagaimana media 
massa lainnya, komik digital juga memiliki beberapa fungsi, yaitu fungsi surveilance (pengawasan), fungsi interpretation (penafsiran), fungsi linkage (keterkaitan), fungsi transmission of value (penyebaran nilai) (dalam Ardianto, 2007: 14).

Di samping memiliki sejumlah fungsi sebagaimana tersebut di atas, komik digital pun rentan menjadi media yang turut melanggengkan konstruksi sosial dominan, termasuk dalam hal kontruksi dan diskriminasi terhadap perempuan. Menurut Banton (dalam Sunarto, 2004: 161), diskriminasi merupakan perlakuan membedakan terhadap orang lain berdasarkan kelompok tertentu. Perempuan merupakan salah satu kelompok masyarakat yang seringkali mengalami tindakan diskriminatif tersebut. Diskriminasi diterima perempuan baik dalam kehidupan sosial maupun bermedia. Baik di media konvensional maupun dalam media digital.

Diskriminasi dalam media umumnya hadir melalui beragam penggunaan bahasa dan tanda. Roland Barthes merupakan salah satu tokoh strukturalis yang gemar mempraktikan model linguistik dan semiologi Saussurean. Ia berpendapat bahwa bahasa merupakan sebuah sistem tanda yang mencerminkan asumsi-asumsi dari suatu masyarakat tertentu dalam waktu yang tertentu juga (dalam Sobur, 2017: 63). Tanda itu sendiri didefinisikan sebagai sesuatu yang dapat mewakili sesuatu yang lain atas dasar konvensi sosial.

\section{Hasil dan Pembahasan}

\section{Webtoon The Secret of Angel: Realita Berbungkus Cerita}

Author atau biasa dikenal dengan kreator pembuat komik digital Webtoon The Secret of Angel adalah Yaongyi. Wanita berusia 28 tahun ini bekerja sebagai model sebelum menjadi kreator pembuat komik di webtoon. Ide cerita komiknya dikembangkan berdasarkan pengalamannya sebagai seorang model (Bima, 2020). Yaongyi menerbitkan komik pertamanya di aplikasi Naver Webtoon yaitu aplikasi webtoon yang ada di negara Korea dengan judul "Everybody Has Secret". Komik itu memiliki ide cerita yang kurang lebih sama dengan The Secret of Angel namun dengan tokoh utama laki-laki bernama Seungho Lee yang memiliki wajah jelek dan gendut dan membuatnya disepelekan oleh teman-temannya dan kemudian bertekad untuk menjadi tampan. Yaongyi mengaku beberapa cerita yang ada di dalam komik karyanya merupakan pengalaman pribadi yang dialaminya. Sebagai model Yaongyi banyak melihat bagaimana perlakuan yang diterima oleh seseorang yang memiliki penampilan menarik dan tidak serta bagaimana kehidupan seseorang sangat bisa ditentukan oleh penampilannya. Yaongyi mengakui bahwa penampilan yang ia tampilkan sekarang sama sebagai model dengan penampilan Ju-Kyung yang ada di dalam komik yang dia tulis.

Webtoon The Secret of Angel menceritakan seorang perempuan bernama JuKyung yang tak percaya diri karena memiliki wajah biasa-biasa saja jika dibandingkan dengan kakak perempuannya. Ketika duduk di bangku SMP, JuKyung dibully dan kerap dijauhi oleh teman sekelasnya. Dia pun berusaha dengan keras belajar dandan dan menghabiskan tabungan untuk membeli alat make-up. Wajah Ju-Kyung yang sebelumnya kurang cantik kemudian berubah menjadi wajah layaknya seorang angel. Setelah memiliki wajah yang cantik, Ju-Kyung menjadi mudah mendapatkan teman dan disukai siapapun. 


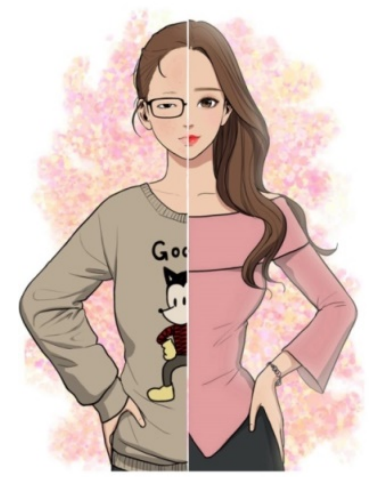

Gambar 1. Tokoh Utama: Ju-Kyung Li

\section{Sebutan Untuk Perempuan dalam The Secret of Angel: Sebuah Analisis Isi}

Banyak penelitian terdahulu yang menghasilkan simpulan bahwa perempuan lebih banyak direpresentasikan secara negatif di media. Media juga diyakini telah menjadi salah satu agen yang melanggengkan konstruksi sosial yang bias tentang perempuan. Oleh karena itu, pada tahap pertama penelitian ini, peneliti telah melakukan analisis isi terhadap beragam ujaran yang digunakan untuk menyebut perempuan atau ditujukan untuk mendeskripsikan tentang perempuan dalam webtoon The Secret of Angel ini.

Analisis isi dilakukan terhadap Webtoon The Secret of Angel dalam kurun waktu 19 Mei 2018 sampai 9 Desember 2019 yang terdiri dari 89 episode dan 5 episode tambahan. Unit analisis yang menjadi objek penelitian adalah ujaran atau sebutan yang ditujukan kepada perempuan dan kepada laki-laki. Beberapa contoh ujaran untuk perempuan antara lain adalah cantik, manis, cakep, bidadari, jago masak, badannya bagus, langsing, sadis badannya, bersinar, elegan, jelek, jerawatan, cup A, bawel, tepos, make up tebal dan sebagainya. Sementara sebutan untuk laki-laki di antaranya keren, jago, ganteng, jago main game, berkarisma, dewasa, tinggi, menjijikkan, gila, preman, picik, kasar, cecunguk dan sebagainya.

Berdasarkan hasil analisis isi terhadap ujaran dan sebutan yang ditujukan kepada perempuan dan laki-laki, diketahui bahwa terdapat 227 ujaran positif dan 119 ujaran negatif yang ditujukan kepada perempuan. Sementara ujaran yang ditujukan kepada laki-laki ada 175 ujaran positif dan 143 ujaran negatif. Jika disajikan dalam bentuk diagram maka prosentasenya akan tampak sebagai berikut: 


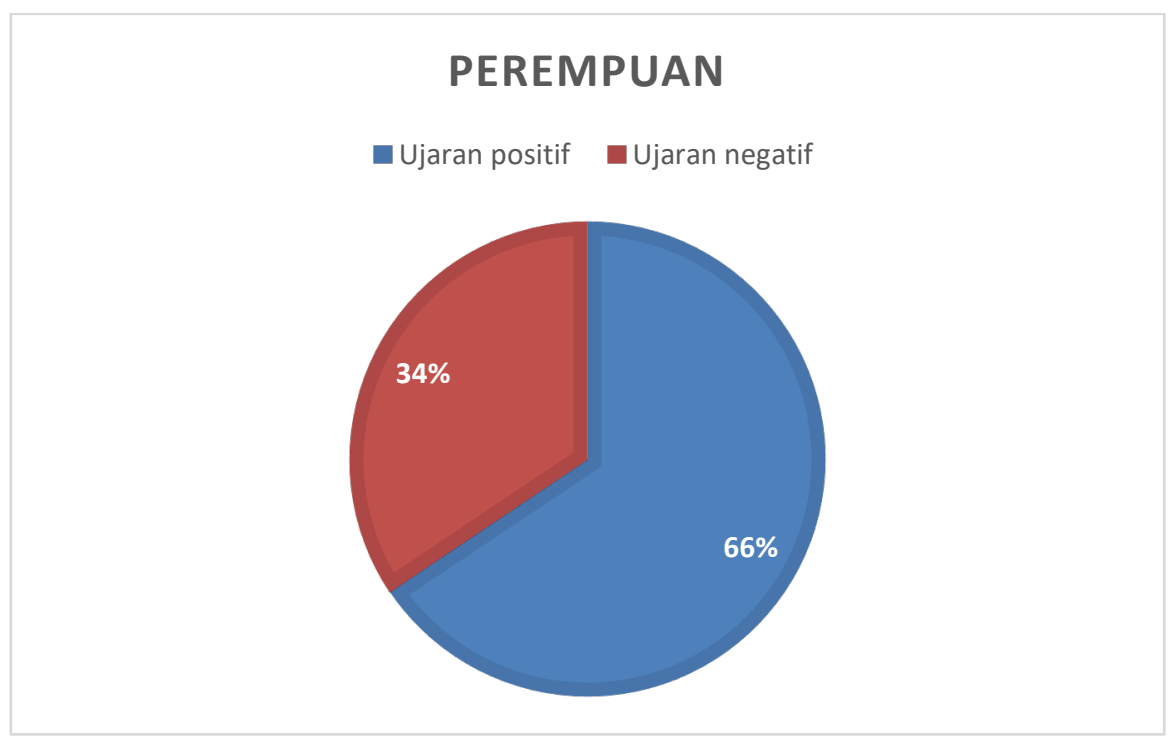

Berdasarkan data di atas, maka diketahui bahwa secara denotatif, kata-kata yang ditujukan untuk perempuan lebih banyak merupakan kata-kata yang positif. Kata-kata positif mencapai $66 \%$ dari keseluruhan ujaran yang ditujukan kepada perempuan. Sementara itu jika dibandingkan dengan kata-kata untuk laki-laki maka diketahui bahwa secara jumlah, laki-laki juga menerima ujaran atau sebutan positif lebih banyak dari kata-kata negatif meskipun selisih prosentase di antara keduanya relative tidak terlalu jauh.

\section{Laki-laki}

- Ujaran Positif Ujaran Negatif

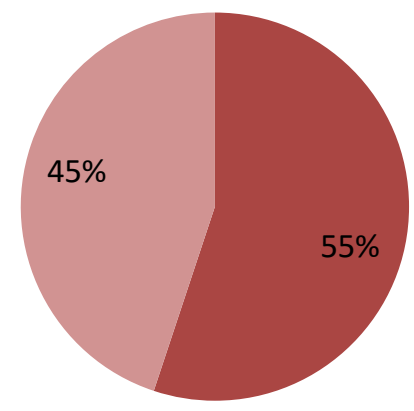

Dari hasil diagram di atas, laki-laki menerima 55\% ujaran positif dan $45 \%$ untuk ujaran negatif. Jika melihat selisih prosentase yang berdekatan maka hingga tataran ini, dapat dibuat simpulan sementara jika laki-laki justru menerima katakata negatif lebih banyak daripada perempuan. Perempuan menerima $34 \%$ katakata negatif sementara laki-laki menerima kata-kata negative sebanyak 45\%.

Data kuantitatif tersebut diperoleh melalui analisis isi dengan menghitung frekwensi kemunculan unit analisis dalam episode-episode The Secret of Angel. Hasil analisis isi menunjukkan bahwa secara kuantitatif diskriminasi yang 
ditudingkan telah dilakukan media terhadap perempuan ternyata tidak ditemukan. Sebaliknya, laki-laki dan perempuan sama-sama menerima ujaran maupun sebutan positif lebih banyak daripada sebutan negative. Bahkan laki-laki justru menerima ujaran negatif lebih banyak dari perempuan. Hasil analisis isi yang berbeda dengan asumsi umum merupakan hal yang lazim dalam penelitian. Salah satu penyebab perbedaan adalah bahwa asumsi umum memiliki subjektivitas yang tinggi sementara analisis isi lebih bebas nilai dan objektif.

\section{Polysemic Positif dan Negatif: Analisis Semiotik Atas Representasi Perempuan dalam The Secret of Angel}

Pada komik The Secret of Angel ujaran positif diarahkan pada perempuan yang dianggap cantik ketika memiliki badan bagus, wajah yang kecil, mata yang besar, kulit bagus, kulit putih, hidung mancung, dada besar. Visualisasi tersebut tergambar pada karakter Ju-Kyung setelah dia memakai make-up untuk menutupi wajah aslinya. Kerap kali Ju-Kyung mendapatkan julukan Angel karena kecantikannya dipandang seperti bidadari yang berada di dalam dongeng atau cerita-cerita fantasi. 


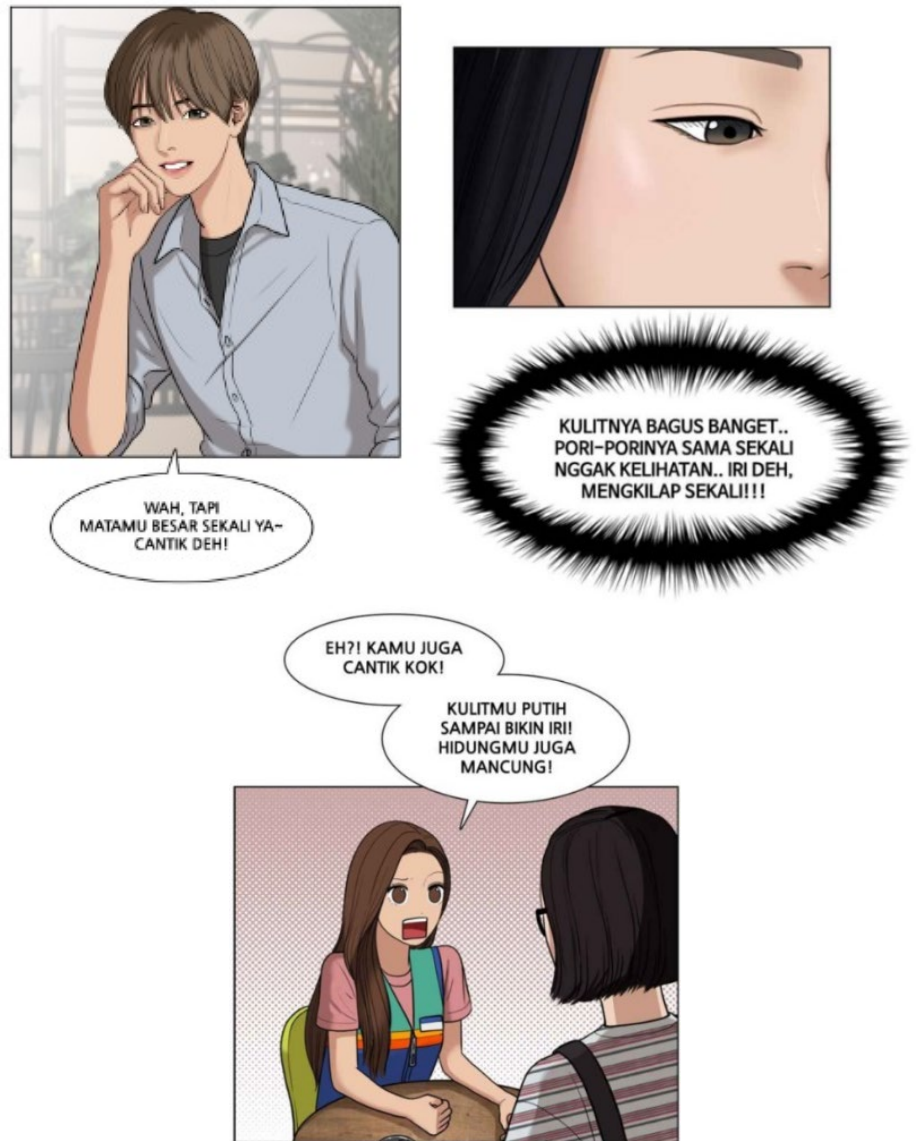

Gambar 2. Contoh Ujaran-ujaran Positif

Cuplikan gambar di atas memperlihatkan bagaimana kata-kata yang digunakan untuk mendeskripsikan sosok perempuan cantik. Untuk cuplikan di atas semua kata-kata yang digunakan memiliki makna positif baik secara denotatif maupun konotatif. Tetapi karena semua kata-kata bersifat polysemic, maka tidak semua kata-kata positif secara otomatis juga memiliki makna positif, demikian pula kata-kata negatif tidak serta merta bermakna negatif.

Salah satu standar penilaian kecantikan perempuan adalah tubuh yang bagus. Media merepresentasikan berbagai macam tipe ideal tubuh perempuan yang masuk kriteria cantik. Citra tubuh perempuan ideal yang dikonstruksi oleh media dna kemudian menjadi kontruksi sosial dominan adalah perut rata, langsing, lengan dan paha yang kencang serta bebas dari lemak yang menimbun.

Untuk memperoleh tubuh ideal tersebut, perempuan melakukan berbagai cara mulai latihan fisik dan diet yang ketat hingga sedot lemak dan meminum obat pelangsing. Bentuk tubuh yang dianggap ideal selalu berubah-ubah sesuai dengan zaman dan kultur budaya yang ada di suatu masyarakat. Contohnya adalah perubahan standar tubuh ideal perempuan dalam budaya Barat. Pada tahun 1600- 
an, ungkapan "Rubenesque" merupakan sebutan lain pada perempuan bertubuh plus-sized atau besar. Perempuan bertubuh besar dianggap memilki kehidupan yang lebih makmur dan dianggap berkelas dibandingkan perempuan dengan bentuk tubuh lainnya. Berganti lagi pada tahun 1900 saat kebugaran tubuh menjadi perhatian utama masyarakat. Bentuk tubuh atletis dengan dada rata seperti tubuh remaja laki-laki, menjadi bentuk tubuh yang ideal bagi sebagian kaum perempuan. Tetapi, pada pertengahan tahun 1900-an, standar tubuh ideal terbagi menjadi dua yaitu bentuk tubuh hourglass dan kurus. Lalu, memasuki tahun 1990 standar tubuh ideal mulai beragam. Contohnya, Kate Moss merupakan model internasional menjadi panutan sebagian perempuan yang ingin memiliki tubuh tinggi dan kurus kecil. Di sisi lain, aktris Pamela Anderson menjadi panutan tubuh berlekuk dan berdada besar. Pada saat ini, standar ideal tubuh perempuan terbagi menjadi tiga, yaitu berisi, langsing, dan kurus.

Hingga tataran ini, tampak bahwa perempuan seringkali tidak punya kuasa atas tubuhnya sendiri. Perempuan harus menyesuaikan diri dengan standar tubuh yang ada dan menjadi mitos di masyarakat sebagai standar tubuh ideal. Kondisi tersebut kemudian terepresentasi dalam komik termasuk Webtoon The Secret of Angel. Banyak adegan dan kata-kata yang kemudian menceritakan tentang tubuh indah dan priviledge yang diperoleh perempuan jika memilikinya. Shilling (1996) menyatakan bahwa perempuan sudah termakan dengan konstruksi yang dibuat dan ada di masyarakat, seperti memandang dan menempatkan tubuhnya sebagai objek dari orang lain. Tubuh perempuan bukan dijadikan objek pornografi, melainkan sebuah erotika yang berbunga-bunga romantic menciptakan sebuah citra sensual yang tak hanya dinikmati oleh pembaca laki-laki, namun juga perempuan. Perempuan menciptakan sebuah gambaran standar terhadap tubuh mereka sendiri (dalam Prayogo, 2015: 34).

Bourdieu dan Passeron (1990) juga mengatakan bahwa tubuh, seksualitas dan identitas dikonstruksi secara sosial. Konsep tentang tubuh ideal yang memiliki tubuh langsing, tinggi, paha kecil, pinggang kecil dan bokong yang besar pada akhirnya diterima secara sosial dan menjadi peraturan-peraturan yang 'harus' diterima dan dipatuhi (dalam Murwani, 2010: 15). Seperti yang dialami oleh Sujin pada episode ke-25 sampai episode ke-26, berikut potongan scene pada komik.
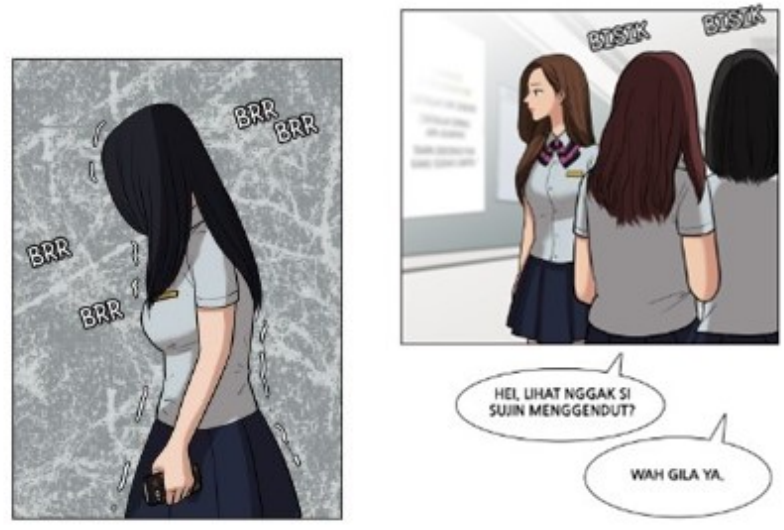

Gambar 3. Potongan Scene Episode 25 dan Episode 26 
Perubahan pada bentuk badan Sujin dari memiliki badan yang dianggap ideal di masyakarat menjadi lebih gemuk, telah membuat pendapat orang mengenai Sujin berubah dratis.

Selain badan, wajah adalah bagian tubuh perempuan yang menentukan kriteria penilaian cantik dan tidak cantik. Sudah menjadi hal yang lumrah di Korea Selatan untuk melakukan operasi plastik demi mendapatkan wajah yang kecil dan mungil. Hal ini dibuktikan dengan banyaknya perempuan bahkan laki-laki yang melakukan operasi plastik. Wajah kecil di Korea Selatan dianggap sebagai salah satu ciri dari perempuan cantik, hal ini terbukti dalam penelitian yang dilakukan oleh Nadya Esvandiary (2014) yang mengungkapkan bahwa pemotongan rahang menjadi lebih ramping berbentuk $\mathrm{V}$ menjadi ideal para perempuan di Korea Selatan, selain memperlihatkan sisi feminim dan tampak awet muda.

$V$-Shape Face juga dikenal sebagai $V$-Line Face, merupakan bentuk wajah tirus dan oval yang menyempit ke arah dagu (Gunawan, dalam Halim, 2020: 16 ). Selain mengubah bentuk wajah menjadi lebih kecil, operasi plastik yang mengubah kelopak mata menjadi lebih besar merupakan hal yang lumrah juga di Korea Selatan. Jika tidak melakukan operasi maka penggunaan make up atau soft lens dapat menjadi solusi untuk mendapatkan mata lebih besar yang diyakini membuat perempuan menjadi lebih cantik sebagaimana ditampilkan dalam komik digital Webtoon The Secret of Angel pada episode ke-3.
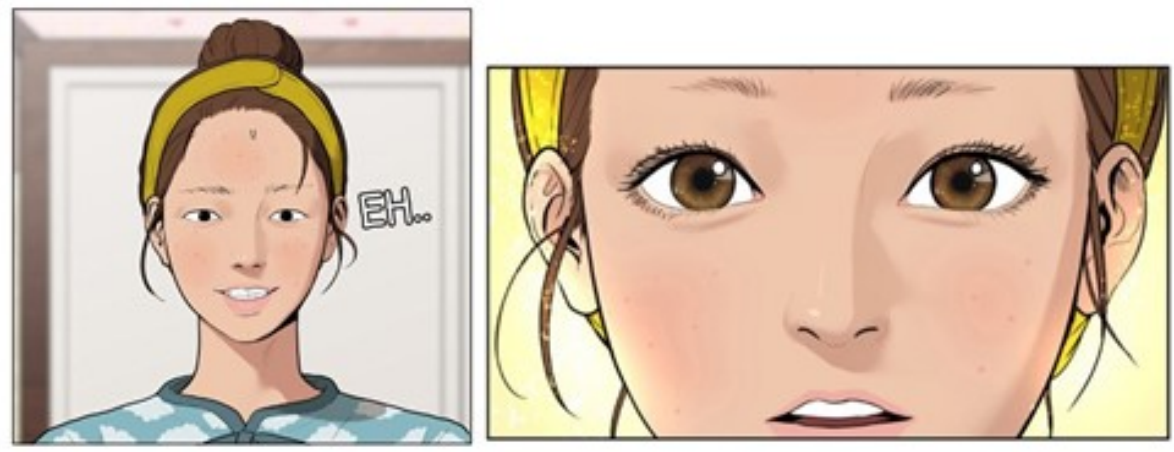

Gambar 4 Potongan Scene Episode 3 Sebelum dan Sesudah Menggunakan Kontak Lensa

Kulit bagus juga menjadi standar kecantikan dan sering membuat perempuan yang dipandang tidak cantik karena memiliki kulit bermasalah menjadi kerepotan. Perempuan harus berusaha menutup noda atau masalah di kulit wajahnya dengan berbagai make up atau juga operasi. Mitos bahwa kulit yang mulus adalah salah satu standar cantik membuat banyak orang berusaha memberikan solusi dan menghadirkan trend baru seperti para beauty vlogger di Youtube.

Hidung merupakan salah satu pusat perhatian dari wajah seseorang. Hidung yang mancung memberikan aksen sehingga wajah terlihat lebih cantik dan menarik. Pada Kumpulan Cerpen Menulis Tubuh, terbitan Jurnal Perempuan tahun 2012, terdapat beberapa cerpen yang menggambarkan perempuan mancung sebagai perempuan yang dianggap cantik di masyarakat, salah satunya cerpen berjudul "Dua Wanita Cantik" karya Jujur Prananto. 
Dada besar, juga merupakan bagian tubuh perempuan yang menjadi standar kecantikan yang terepresentasi dalam webtoon The Secret of Angel. Dalam salah satu adegannya digambarkan Ju-Kyung iri dengan perempuan yang sedang mengobrol dengan Suho karena memiliki ukuran dada lebih besar. Mitos yang meyakini bahwa dada besar membuat perempuan lebih cantik membuat perempuan berusaha memenuhi standar tersebut. Ketika standar dada cantik tidak terpenuhi, tidak jarang perempuan kemudian melakukan implant atau menggunakan obat atau pakaian yang dapat menampilkan kesan payudara yang lebih besar.

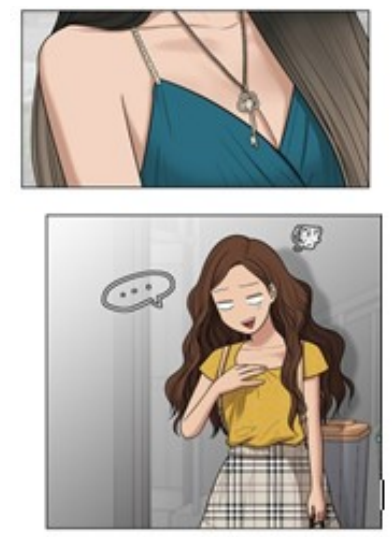

Gambar 5. Ju-Kyung (bawah) membandingkan dadanya dengan dada perempuan lain yang dipandang lebih menarik pada episode 46

\section{Diskriminasi Terhadap Perempuan Tidak Cantik}

Kehidupan Ju-Kyung sebelum mengenal make-up dengan sesudah JuKyung menggunakan make-up sangatlah bertolak belakang, dari perlakuan yang diterima hingga julukan yang diberikan kepadanya. Pada gambar episode ke-7 JuKyung ditampilkan sedang mengingat bagaimana ia diperlakukan buruk oleh orang sekitar karena memiliki penampilan fisik yang tidak cantik. Sebutan yang diarahkan pada Ju-Kyung pada episode ke-7 adalah "bikin sakit mata" yang berarti tidak enak dilihat. Ujaran kasar yang ditujukan pada Ju-Kyung dapat digolongkan ke dalam perlakuan bullying. Menurut Olweus (1993) bullying secara verbal merupakan bullying yang paling mudah dilakukan karena bullying dalam bentuk ini menggunakan kata ejekan untuk memberikan julukan kepada seseorang.

Selain kekerasan verbal, tindakan diskriminatif terhadap perempuan yang dipandang tidak cantik juga bisa berupa perlakuan yang berbeda. Pada episode 18 Ju-Kyung yang tidak cantik tidak sengaja menumpahkan minuman ke baju seorang laki-laki yang sedang duduk. Hal ini membuat laki-laki tersebut marah sehingga mengintimidasi Ju-Kyung. Perlakuan yang berbeda ditunjukkan oleh lelaki yang sama pada episode ke-22 ketika Ju-Kyung sudah menggunakan make-up dan terlihat cantik. Tidak hanya orang lain, bahkan keluarga sendiri termasuk ibu berpotensi melakukan kekerasan kepada anak yang dianggap tidak menarik sebagaimana ditampilkan dalam adegan Ju-Kyung dan ibunya pada episode ke-25 ketika ibu Ju-Kyung memanggil dan memperlakukan tiga anaknya secara berbeda. 
Perlakuan diskriminatif juga diterima perempuan yang dianggap tidak cantik dari lingkungan pergaulannya. Digambarkan pada episode ke-2 Ju-Kyung yang belum mengenal make-up berangkat sekolah dan menjadi bahan tertawaan oleh teman satu kelasnya. Ju-Kyung tidak mempunyai teman saat SMP karena penampilan fisiknya yang tidak cantik. Penerimaan lingkungan terhadap Ju-Kyung sangat berbeda ketika dia sudah di SMA dan menggunakan make-up. Dapat dilihat dari dialog yang ada pada episode ke-3, "Kamu cantik banget deh Tukaran nomor yuk."

\section{Kesimpulan}

Berdasarkan hasil analisis yang dilakukan maka diperoleh simpulan bahwa secara kuantitatif perempuan dalam webtoon The Secret of Angel direpresentasikan secara positif. Hal tersebut disimpulkan dari hasil analisis isi dimana perempuan memperoleh lebih banyak sebutan positif (66\%) daripada sebutan negatif. Namun demikian, ketika dilakukan analisis secara semiotic dengan melihat makna denotasi, konotasi dan mitos yang melekat pada ujaran-ujaran tersebut, ternyata sebuat positif tidak serta merta bermakna positif pula. Ujaran-ujaran positif lebih banyak digunakan sebagai standar kecantikan untuk perempuan yang jika tidak terpenuhi rentan menempatkan mereka dalam posisi terdiskriminasi. Diskriminasi terhadap perempuan yang dianggap tidak cantik antara lain berupa kekerasan verbal, fisik dan psikis.

Akibat standar kecantikan yang menjadi konstruksi sosial dominan di masyarakat itulah, perempuan kemudian dipaksa untuk menyesuaikan diri bahkan membentuk tubuhnya dengan beragam cara mulai dari obat, operasi hingga penggunaan make up.

\section{DAFTAR PUSTAKA}

Bima, Amadeus. 2020. Pesona Author The Secret of Angel, Yaongyi Webtoonist Ini Punya Wajah Cantik. [Online]. https://keepo.me/viral/author-the-secret-ofangel-ini-bikin-banyak-fans-terkesima-karena-punya-wajah-cantik-miripkarakter-ciptaannya/, diakses pada 24 Maret 2020.

Esvandiary, Nadya. 2014. "Cosmetic Surgery and Women Disparities in South Korea”. Jurusan Hubungan Internasional. 2, (1), 1-13.

Halim, Argo. 2020. "How to Make V-Shape Korean Face”. Jurnal Universitas Kristen Indonesia. 14, (16), 1-71.

J. Cavico, Frank, Stephen C. Muffler dan Bahaudin G. Mujtaba. 2012. “Appearance Discrimination, "Lookism" And "Lookphobia" In The Workplace". The Journal of Applied Business Research. 28, (5), 791-802. 
Kasiyan. 2008. Manipulasi dan Dehumanisasi Perempuan dalam Iklan. Yogyakarta: Ombak.

Khani Arani, Hossein dan Sajad Davoudi Mobarakeh. 2011. "Sociolinguistics: Education, Women, Beauty, Discrimination \& Exploitation: Investigating the Ugly Reality". International Journal of Humanities and Social Science. 1, (21), 1-10.

Murwani, Endah. 2010. “Konstruksi 'Bentuk Tubuh Perempuan' Dalam Iklan Televisi”. Jurnal Ilmu Komunikasi. 2, (1), 10-19.

Ponco Putranto, Arif. 2017. "Konstruksi Cantik Mahasiswa pada Media Sosial Melalui Akun Instagram @unnes_cantik”. Skripsi pada Jurusan Sosiologi dan Antropologi Universitas Negeri Semarang: tidak diterbitkan.

Prayogo, Ardianto. 2015. "Gambaran Sensualitas Tubuh Perempuan dalam Komik One Piece”. Commonline Departemen Komunikasi. 4, (2), 22-35.

Setyadharma, Adelia. 2014. Diskriminasi Kelompok Minoritas di Indonesia. [Online]. http://isbd-alv.blogspot.com/2014/03/diskriminasi-kelompokminoritas-di.html, diakses pada tanggal 31 Oktober 2019.

Sobur, Alex. 2017. Semiotika Komunikasi. Edisi kelima. Bandung: Remaja Rosdakarya.

Sunarto, Kamanto. 2004. Pengantar Sosiologi (edisi kedua). Jakarta : Lembaga Penerbit Fakultas Ekonomi, Universitas Indonesia.

Wawan Jatnika, Asep dan Ferry Fauzi Hermawan. 2018. "Menjadi Lelaki Sejati : Maskulinitas Dalam Komik Daring Webtoon Indonesia". Jurnal Seni Budaya. 33, (1), 60-66. 